\title{
Learning to Co-compose Curriculum with Youth
}

\author{
M. Shaun Murphy \\ University of Saskatchewan \\ Canada \\ Viviane Bengezen \\ Federal University of Uberlandia \\ Brazil
}

\begin{abstract}
In this paper we trace the experiences of a teacher, Viviane, as she learns to cocompose curriculum alongside a youth. The conceptualizations of personal practical knowledge, personal and professional knowledge landscapes, familial and school curriculum making, and stories to live by shape our narrative understanding of curriculum making as relational work attentive to the making of a life for a youth in school, and her teacher. Our paper also takes up a second phenomenon, which explores our coming to a conceptual understanding of curriculum making in practice as a narrative act for a teacher and a teacher educator.
\end{abstract}

\section{Beginning with Viviane's Storied Experience}

One day in May, the principal of Escola Aquarela, where I had been working since 2010, asked me to help Catarina with a Math test. She always requires somebody to read her the tests because she has low vision. I was not sure of what I had to do to help Catarina. I couldn't solve any of the exercises on the test for her because of the test-taking rules (and my own mathematical ability), but neither could Catarina. The first thing I thought about was helping her to read it. She told me that the letters had to be bigger. One device she knew of that might help her was the Iris 22 (an electronic magnifier for low vision). I helped her to keep focused, asking her what she understood about the Math problems; we went back and forth many times, so she could make sense of the sentences. From her feedback I realized that she didn't know what the symbol "\%" meant, and she couldn't read larger numerals. Catarina was not able to tell me which day it was, nor the year in which she was born, all parts of the test she had to complete. 
A couple of days after this experience, the principal asked me if I wanted to work in the mornings as a support teacher for Catarina. In order to support Catarina better, I attended a meeting to learn about what could be done. The following illustrates what I learned:

This morning, along with my coordinator from AEE (Atendimento Educacional Especializado - Specialized Educational Service ${ }^{\mathrm{i}}$ ) I went to $\mathrm{CEMEPE}^{\mathrm{ii}}$ to talk to the general coordinator of AEE about my role and responsibilities as a support teacher. She said that she did not know what my duties were exactly, because it was something new in our school system. So we had to learn by doing, but she had some directions: (i) I needed to use a large notebook, white sheets (size A3) and large and colorful pens, always working with the color contrast. I could use the laptop, since Catarina was learning how to use Virtual Vision iii; (ii) Catarina and I could leave the classroom for private teaching one hour per day, for pedagogical support. (Interim research text, November, 2013)

As Viviane left the meeting described in the interim research text, she had many questions, such as: How could regular teachers support Catarina within the classroom? How could she, Viviane, develop adapted papers and tests and be supportive? How could Catarina learn to read and produce texts? What did inclusion mean for Catarina?

In this paper we trace the experiences of a teacher, Viviane, as she learned to co-compose curriculum alongside a youth, Catarina, in a Brazilian public school. Shaun was a visiting professor at Viviane's university in Brazil when she invited him to inquire into her experiences alongside her as she struggled to make sense of her work with Catarina. Viviane was looking for a conceptual frame that would help her understand her practice. In this paper Shaun and Viviane think together about her practice in the midst of being a teacher alongside Catarina. Viviane was in the process of curriculum making (Clandinin \& Connelly, 1992) yet did not use these words to describe her practice as she began to tell her stories. Shaun began to understand Viviane's experience as an act of co-composing curriculum, and, together, Shaun and Viviane began to inquire narratively into what they began to call Viviane's experience of curriculum making.

Our narrative inquiry (Clandinin \& Connelly, 2000) in this paper makes central Viviane's experience as a support teacher alongside Catarina, ${ }^{\text {iv }}$ a youth in 9th grade with low vision, as they co-composed curriculum in relation with one another. Viviane's questions of who she is and who she is becoming in relation with Catarina turned our attention toward curriculum making, understood "as an account of teachers' and children's lives together in schools and classrooms" (Clandinin \& Connelly, 1992, p. 392). We also take up wonders of what it means to understand curriculum making and therefore enter into an inquiry in curriculum making into what began a kind of teacher education between Shaun and Viviane.

\section{Situating our Inquiry}

Our inquiry into Viviane and Catarina's curriculum making (Connelly \& Clandinin, 1988), a narrative concept that attends to the life writing (Clandinin et al., 2006) of teachers and children/youth when their lives meet in schools, is what shapes this paper. We understand life writing to be the ways we write our lives as we compose our stories to live by (Connelly \& Clandinin, 1999), a narrative term for identity. By inquiring into the co-composed curriculum making between Viviane and Catarina, we began to wonder: What does it mean to shift our attention to a focus on curriculum making based on relationships and lives in the making? 
As Viviane came to understand her work alongside Catarina, she shaped her personal practical knowledge (Clandinin \& Connelly, 1995) in relation with Catarina. As Viviane gradually came to understand her interactions with Catarina as curriculum making through her work with Shaun, we realized that Catarina was also shaping Viviane's personal practical knowledge. At the same time, Shaun and Viviane came to understand their work together as curriculum making and how we were shaping the other's personal practical knowledge.

In the opening interim research text, Viviane initially wondered how she could support Catarina. Some of this knowledge Viviane gained from other professionals, but most of her knowledge about how to work with Catarina came from Catarina herself. In order to understand this unfolding process, we show how thinking narratively with Viviane's storied experience shapes an understanding of her curriculum making and of how Viviane and Shaun came to understand their experience as one of learning to co-compose curriculum with each other. As we, Viviane and Shaun, worked together it became apparent that there was another phenomenon we were attending to, which was: What does it mean to understand the complexity of curriculum making in the lives of teachers and children/youth? What was the curriculum making of Shaun and Viviane? In upcoming sections we italicize those sections that attend to the second phenomenon.

\section{A Ground for Understanding the Puzzle: Thinking Narratively about Experience}

Narrative is both the method and the phenomenon in a narrative inquiry (Clandinin \& Connelly, 2000), which means we see Viviane's and Catarina's experiences as phenomena. We also see Shaun's experience of coming alongside Viviane as a second phenomenon under study in this paper. Connelly and Clandinin (2006) write:

People shape their daily lives by stories of who they and others are and as they interpret

their past in terms of these stories. Story, in the current idiom, is a portal through which a person enters the world and by which their experience of the world is interpreted and made personally meaningful. Narrative inquiry, the study of experience as story, then, is first and foremost a way of thinking about experience. Narrative inquiry as a methodology entails a view of the phenomenon ... To use narrative inquiry methodology is to adopt a particular view of experience as phenomenon under study. (p. 477)

By narrating stories of Viviane's experiences as a support teacher alongside Catarina, a youth with low vision, inquiring into them and imagining transformations, we corroborate the central commitment of narrative inquirers, which is to contribute to an amelioration of oppressive conditions instead of "simply reproducing narratives that support macro social systems of oppression” (Clandinin \& Rosiek, 2007, p. 51).

We entered the curriculum-making world of Viviane and Catarina through their stories in order to understand their experience, to interpret their worlds. "Lives are lived, told, retold, and relived in storied ways on storied landscapes”(Clandinin \& Murphy, 2009, p. 598) and our retelling is situated in their experience within the larger social, cultural, and institutional narratives that shape schooling in Viviane's and Catarina's Brazilian municipal school. In the paper we also enter the curriculum-making world of Shaun and Viviane as they make sense of Viviane's work as curriculum making.

In order to narratively understand Viviane's curriculum making as a support teacher and researcher with Catarina across school subjects, home, and school, we share Viviane's 
experiences prior to and while working alongside Catarina. We also wonder what Viviane's and Catarina's experiences with curriculum making support us to understand as curriculum scholars. To do this, we situate their experience in relation to the three-dimensional narrative inquiry space (Clandinin \& Connelly, 2000), which is defined by "temporality along one dimension, the personal and social along a second dimension, and place along a third" (p. 50). Clandinin and Connelly (1994) write that the dimensions of temporality and the personal and social have four directions for inquiry:

inward and outward, backward and forward. By inward, we mean toward the internal conditions, such as feelings, hopes, aesthetic reactions, and moral dispositions and so on. By outward, we mean toward the existential conditions, that is, the environment... By backward and forward, we refer to temporality-past, present, future. To experience an experience is to simultaneously experience it in these four ways and to ask questions pointing each way. (p. 158)

By situating their narratives of experience within this narrative framework, we are able to trace the particularities of their curriculum making in relation to place, the temporality of their experiences, and their interactions with each other and others.

\section{Viviane's Personal Knowledge Landscape and the Narrative Commonplaces}

In what follows, Viviane recounts an experience from her adolescence when she began to attend to diverse people and their experience. This, and other experiences Viviane shared with Shaun, shaped her stories to live by. According to Huber, Murphy, and Clandinin (2003), "Stories to live by attend to the historical, the temporal, the contextual, and the relational. Stories to live by interconnect teachers' personal practical knowledge with their professional knowledge contexts" (p. 347). These authors further suggest "Thinking through curriculum and identity in narrative ways means that stories to live by are at the heart of the making and remaking of a curriculum" (p. 347).

Viviane's stories to live by influenced her personal practical knowledge (Clandinin \& Connelly, 1995). Personal practical knowledge, conceptualized by Clandinin and Connelly, refers to "that body of convictions and meanings, conscious or unconscious, that have arisen from experience (intimate, social and traditional) and that are expressed in a person's practices" (p. 7). Personal practical knowledge is essential to understanding how the personal and the practical work together. It is a term

...designed to capture the idea of experience in a way that allows us to talk about teachers as knowledgeable and knowing persons. ... [Personal practical knowledge] is in the person's past experience, in the person's present mind and body, and in the person's future plans and actions. ... it is a particular way of reconstructing the past and the intentions of the future to deal with the exigencies of a present situation. (p. 25) Understanding Viviane's personal practical knowledge in terms of "narrative life history, as storied life compositions" (p. 2) implies that "these stories, these narratives of experience, are both personal - reflecting a person's life history - and social - reflecting the milieu, the contexts in which teachers live" (p. 2). Personal practical knowledge in relation with stories to live by allows us to consider the connections among Viviane and Catarina's contexts, knowledge, and identities (Clandinin \& Connelly, 1995).

Viviane's narrative beginning initiated our inquiry into her puzzling around what it

meant to co-compose curriculum with a youth, as well as Shaun's coming alongside Viviane in 
order to help her conceptualize her work as a process of curriculum making. The following interim research text shows how Viviane's understanding of diverse abilities and her teacher knowledge is something shaped by her knowing over time.

When I was 14 years old, I used to dance ballet. I lived in São Paulo, and every day I went to the Ballet School by subway. At one subway station, called Santa Cruz, I frequently saw a group of deaf teenagers talking with LIBRAS (Língua Brasileira de Sinais -Brazilian Sign Language). This made me curious about their language and I wondered at the time, why my school did not teach me to talk using LIBRAS. In school I felt it was a waste of time to copy the many texts we were expected to copy and to complete so many questions that had such obvious answers. Instead, why not be able to communicate with the deaf? Why not learn communication skills I could use?

I used to observe people at the various subway stations and inside the subway car itself. It was strange, for me, to be so close and at the same time so far from many men and women of all ages, children, teenagers, and babies, listening to or watching their talk, seeing what kind of clothes they wore, what objects they carried, and to imagine where the boys and girls studied or where the people worked. Observing them made me reflect about my own life, school, and family.

Almost every day I had homework to do, and I did not have time to do it, because I practiced many hours of ballet during the afternoons. Therefore, the solution was to do my homework on the way from home to the ballet school, after lunch, inside the subway. I also used to study for school tests in this place. I was very considerate and studied hard, studying all school subjects. However, I saw my schooling as a waste of time, since I saw no connection between school and life.

One afternoon, in the subway, I observed a boy, who seemed to be seven, with his mother. He was touching a bar of chocolate while asking the mother if it was black or white. I realized that the boy couldn't see the chocolate bar because he was blind. In that moment I started to think about how would be the world if I could not see; I did not feel sorry for the boy, but he did start me wondering. I thought about the colours and the light, and if I would understand the shapes or colours as I understood them as a sighted person. I also thought about the boy's life, his family, and his school. I wondered how different it could be from mine.

(field note, memory recall, September 2013)

We highlight Viviane's personal knowledge landscape ${ }^{\mathrm{v}}$ (Clandinin, Schaefer, \& Downey, 2014) as we inquire into this story of Viviane on the subway in relation to the narrative commonplaces of place, temporality, and sociality (Connelly \& Clandinin, 2006). Each of the commonplaces can only be understood in relation to the other commonplaces, and their meanings are always animated in relation with each other. In the following three sections we separate them in order to show the role of each, but we note that we talk about each commonplace by referencing the others.

\section{Place}

The subway is a public place, much like the school, where every day Viviane encountered different people for more than five years, but it was, at the same time, a very private place, because she did not have close contact with others who rode the subway, and therefore, remained separate. In the subway compartment, Viviane was paying attention to peoples' lives and at the 
same time separately living her own. In school Viviane understands this paying attention to the lives of youth in a more intimate way, yet she and they are still living their own lives,

In the classroom it is much the same, I only experience those moments we share together. I only witness those moments from the midst of the students' lives. I know they have past stories and they are going to live future stories, I am not a passive observer about their success or failures, I know I shape an understanding of their experiences, and I must help them. (field note, October 2013)

Viviane connected the subway experiences with her present experiences as a teacher today in a Brazilian public school.

\section{Temporality}

Looking backward, Viviane talked about the subway and how she felt about the boy who was blind or the teenagers who were deaf and her own landscape of school as a teenager, which she saw as disconnected from her life. Looking forward as a researcher and teacher, she notes her tensions as a teacher who helps youth make sense of who they are as learners and who they are becoming. Viviane notes,

Since we spend a whole year in the same classroom, I need to be as good as I can to help them through this specific period of time. (field note, October, 2013)

The backward and forward movement across her experiences over time attends to the dimension of temporality, and is related to how Viviane imagines a way forward as a teacher. Narrative inquiry as a methodology is always in the midst of lives; it always attends to a life in its making, always considers that experience has occurred and will occur. Viviane's experience on the subway metaphorically and concretely represents being in the midst of lives as they are lived. Viviane did not have any idea of what was happening in subway compartments ahead or behind the one she sat in; she had no idea of the living that was happening in those places, nor did she have any knowledge of what the people had done before getting on the subway or what they would do when they departed. In her current life as a teacher Viviane understands that the youth with whom she works bring past experiences to school and will have future experiences after being with her. Specifically, she understands Catarina's life to be a complex making, one that has been shaped over time and will continue to be shaped.

\section{Sociality}

Sociality, the third dimension of the three-dimensional narrative inquiry space, is understood here as Viviane's interaction with other people, such as Catarina, and her internal interaction with the self. In the subway, she was only observing and she kept her distance. In the school, however, Viviane feels as though she is part of the youths' lives, with great responsibilities. While writing and reading the story about the subway, Viviane wondered about how to work alongside a youth who does not fit within the educational system. The memory of when Viviane was a teenager shows some of her experiences in the subway of São Paulo and her thoughts about people and diversity. For Viviane the adolescent, there was a gap between school and life. Even though she was a good student, with excellent grades, she felt she could learn more significant things. She brought this tension regarding formal education to her work with Catarina.

Telling stories about her experiences in the subway helped Viviane and Shaun understand a personal aspect of Viviane as a teacher of Catarina. The story of the subway was one of the first stories Viviane brought to our work together. For her it was a story of coming to 
think about difference, a way for her to situate her inquiry into co-composing curriculum with Catarina and in relation with her personal experience. This story is one that came back to her once she began to work with Catarina.

Viviane's experiences shape her identity as a teacher, her story to live by. Her story to live by was shaped by stories of relationships with others, stories of school contexts, and stories of familial relationships. After telling the story of her experience on the subway, Viviane wondered what this story says about her. How is her personal knowledge landscape in relationship with her professional knowledge landscape? ${ }^{\mathrm{vi}}$ As Viviane engaged in this inquiry into the first phenomenon, her curriculum making alongside Catarina, she also engaged in understanding the wholeness of Catarina's life, just as she engaged in understanding the wholeness of her own life. Viviane writes,

The subway story helped me understand the imaginative act necessary in composing my own story to live by and the need for imagination in curriculum making. My understanding of imagination is shaped by Sarbin (2004), who wrote, "with this 'as if' skill, the actor can interact with narrative constructed events that are spatially distant and temporally remote, he or she can relocate self to different times and places" (p. 11). It means that there are always different possibilities for our stories to live by, youth and teachers together. (field note, December, 2013)

By bringing forward her personal experience to think about her practical work as a teacher, Viviane made visible the narrative concept of personal practical knowledge. Viviane related her past experience as a youth attending to the experiences of others not like herself. This past experience shapes her present day personal practical knowledge as a teacher.

As Viviane came to know about Catarina by working with her, she also came to see Catarina as a knowledgeable person, a person who brought personal practical knowledge to their work together.

Today I asked again about the magnifier on the screen. I asked her to teach me how to use it. And she taught me. She told me to type the word lupa [magnifying] on the corner at the bottom of the screen. She said, "simply put the letter L and it will appear." This was fantastic, because after almost seven months I finally learned how she could read on the screen, and she taught me this naturally and with so much patience. I thought the best for her was to use Virtual Vision, but after all, I understood that she had a different preference: she wanted to read with her eyes, using a magnifying, instead of hearing a synthesized voice. (field text, conversation, November 2013).

When Viviane reread this field note, she realized how she had the opportunity to learn from Catarina, and how teaching Catarina was an opportunity for her to understand curriculum in a new way, more as a course of life (Connelly \& Clandinin, 1988) than a course of studies. Viviane also wondered if Catarina had ever been positioned as a teacher in her life and how this would be important for her, to teach something to somebody. Shaun knew from his own teaching with children and teachers that being a teacher was a significant part of being a learner; it was essential in constructing a reciprocal curriculum making relationship. He had also explored the importance of children's knowledge and relationships in the classroom in previous work (Murphy, 2004; 2009; 2011).

In this moment Catarina and Viviane shifted identities: Catarina became the teacher and Viviane was the learner. Viviane wrote,

Day by day, I was living the experiences alongside Catarina and learning how to be her support teacher. But I knew that first of all, I had to know Catarina. 
(field note, November 2013)

It would seem that in this co-composed curriculum making Catarina was also coming to know Viviane as a learner. While this co-composition might sound smooth, the process for Viviane had moments of tension. The act of curriculum making is an active unfolding way of being without a linear trajectory or map. Curriculum making is recursive by nature and a negotiation of lives. This way of living alongside children and youth shapes tensions between teachers and learners and the dominant story of school based on subject matters and external assessment.

\section{Tension on the School Landscape}

In the following section we make visible some of the tensions Viviane and Catarina experienced on the school landscape. It is important to note that tension was something both Viviane and Catarina experienced. It seemed that Catarina did not see the relevance of reading and writing. One morning, Viviane and Catarina had a conversation regarding how she felt about school.

Catarina: The psychologist at Pró-Luz told me that I don't need to read and write. I don't have to go to high school.

Viviane: And what are you going to do next year?

Catarina: The psychologist said that I can do some specific course.

Viviane: What course?

Catarina: I don't know... there are some adapted courses for blind and people with low vision.

Viviane: Do you agree with the psychologist?

Catarina: My mother agrees.

(V. Bengezen, personal communication, October 2013)

As Viviane thought about their conversation, she did not agree with the psychologist's opinion about Catarina learning to read and write; she did wonder if it was necessary for Catarina to learn conjunctions and subordinate clauses as she did not see this as a necessary skill in reading. Perhaps reading strategies and texts that had to do with her life might make more sense to Catarina? Viviane also experienced tension when Catarina shared that her mother agreed with the psychologist about high school.

When Viviane shared the transcript and told Shaun about the conversation, Shaun saw this as a conflict between a story of school as a training ground for employment with Viviane's hopes for Catarina. Shaun sensed that Viviane's curriculum making with Catarina was about curriculum as the unfolding of a course of life (Connelly \& Clandinin, 1988), with no fixed endpoint beyond support for Catarina to become a whole person with choices. Shaun saw in the transcript that Catarina was being shaped into a person where reading and writing were not important for who she might be in the world. Shaun also felt tensions similar to the ones Viviane experienced in this moment with Catarina. A curriculum-making relationship is not a smooth and easy way of being, but its worth lies in the possibilities for a continuity of experience that attends to the educative (Dewey, 1938). Curriculum making is shaped in the interaction between Schwab's (1978) curriculum commonplaces of learner, teacher, subject matter, and milieu. Holding these in positive tension is significant work, but it is work worth doing in its attention to the complexity of lives in the making. This continuity was reflected in Viviane's work alongside Catarina and in Shaun and Viviane's work in coming to understand this practice. 
M. Shaun Murphy \& Viviane Bengezen

\section{Finding a Space for her Daughter}

Catarina's story of the psychologist and her mother is interwoven with another experience for Viviane, one lived in relation with Catarina's mother and her response to Catarina's experiences at school.

I asked her mother when Catarina had come to Escola Aquarela, and how old Catarina was when she came for the first time. "When Catarina was 9, she still couldn't read. I visited her school and saw her sleeping for more than forty minutes. I was so angry and I told the teachers that it would be the last time Catarina would go to school to sleep. So I took her home and used to spend two hours every day with her, saying, "'Go, Catarina, go, you can! Join the letters! Read!' And I taught her how to read.” Once, at another school, they called me saying that Catarina was crying desperately. She was in 5 th grade and I thought that very strange, since my daughter is typically very calm. I went to the school, and Catarina told me that her teacher had torn the sheets of her notebook and held the sheets over Catarina. Her mother told me, "I felt like I had an animal inside me, wanting to be released. I took Catarina and never came back on that school. We came to Escola Aquarela. I've already fought hard for my daughter's rights."(conversation between Catarina's mother and Viviane, November 2013).

Viviane was shocked when Catarina's mother told her that it was she who had taught her Catarina how to read. For Viviane, it was like the school had done nothing for Catarina. So many years, so many hours, and she had not been able to read. Furthermore the experience Catarina's mother related about the torn sheets made Viviane consider how experiences in school had shaped mis-educative moments for Catarina. Viviane wondered, "How mis-educative vii are we being? What kind of students do we know how to deal with? What are we doing about those who live as others? What am I teaching for?" (field note, December 2013), and Shaun agreed.

The above field note also shows the complexity of Catarina's mother's relationship with schooling for Catarina. Earlier, Catarina recounted that her mother agreed with the psychologist. The field note about teaching her daughter to read and moving schools, placed alongside the field note regarding the psychologist's comments, makes visible the tensions for Catarina's mother in relation to their familial curriculum making in regards to Catarina's future. Catarina's mother thought it important for Catarina to read and write, but we wonder if the growing abstraction of reading and writing made no sense to her as a parent hopeful for her child in the world. These field texts show how important it was for Catarina's mother that Catarina find a school place that would respect and value Catarina and her differences and who she might eventually be in worlds away from school. In this way it became evident that Catarina's mother's intent was that Catarina be a literate person able to be successful in her continued life making.

Viviane's experiences over time with diverse people in diverse places continued to shape her stories to live by as a teacher. She brought all of her experiences to her work alongside Catarina; she also brought an understanding that the continuity of Catarina's educational experiences shaped Catarina. Viviane was also coming to an understanding that Catarina's mother's experiences with school shaped Catarina's mother's need to advocate for Catarina.

As Shaun began to understand Viviane's stories of experiences he began to see the complexity necessarily inherent in curriculum making attentive to the whole lives of teachers and youth as they compose their lives in these particular situations and contexts. He also began to see the complex tensions that were part of the negotiations youth, teachers, and families engage in as they shape each other's experiences in co-composed curriculum making. He understood 
curriculum making as a necessary act, but not an easy one. It requires the hard work of staying in relationship, of attending to the whole lives of others, in their contexts, and in their interactions with others.

The idea of life composition as curriculum making shaped a space for Catarina and Viviane. Furthermore, the idea of familial curriculum making (Clandinin, Huber, \& Murphy, 2011; Huber, Murphy, \& Clandinin, 2011; Murphy, Huber, \& Clandinin, 2012) shaped how Viviane was beginning to understand her experiences with Catarina. Huber et al. expanded curriculum making, hitherto mostly understood in relation to school, to include familial curriculum making. This conceptualization of familial curriculum making understands the family, and by extension the community, as sites for curriculum making for children and youth.

\section{The Familial in Curriculum Making}

Earlier in this paper we showed Viviane's life writing (Clandinin et al., 2006) as she attended to the experience of others in an out-of-school place. She brought forward this memory, this shaping event, to contribute to her understanding of Catarina. In the subway narrative, Viviane was situated in a community place, a place she inhabited as she enacted her familial curriculum making of ballet dancing. Huber et al. (2011) write about community spaces as spaces for curriculum making, "home [and] community places as shaped by the stories lived by individual family members and members of broader contexts, each of which are structured by dominant social, cultural [and] linguistic narratives" (p. 18). In the moment on the subway Viviane attends to the people in the space and begins to wonder about dominant social, cultural, and linguistic narratives. She brings these wonderings forward from her own familial curriculum making to her curriculum making alongside Catarina. On the professional knowledge landscape, Catarina is engaged in her own life writing in relation to dominant social, cultural, and institutional narratives. Huber and Clandinin (2005) wrote, "one of the places where lives meet in schools is in curriculum making" (p. 318), and this is where the lives of Catarina and Viviane met. The professional knowledge landscape is composed of

diverse people, things, and events in different relationships. Understanding professional knowledge as comprising a landscape calls for a notion of professional knowledge as composed of a wide variety of components and influenced by a wide variety of people, places, and things. Because we see the professional knowledge landscape as composed of relationships among people, places, and things, we see it as both an intellectual and a moral landscape. (Clandinin \& Connelly, 1995, pp. 4-5)

The complexity of this landscape shapes a complex knowing of the experiences of Viviane, Catarina, Catarina's mother, and Shaun. This moral knowledge landscape attends to the interactions of the various people and places in temporal relationships. It is a knowledge landscape that shapes our knowing of the complexity of Viviane and Catarina's work together. One such complexity was Catarina thinking that not learning to read and write might be okay, and Viviane wondering what this might mean for Catarina.

\section{Understanding Experience in Relationship}

Viviane understands education as a continuum. In conversations with Shaun she referred to Dewey (1938) who defended experience as a way to produce knowledge. Experience, for Dewey, is central to education, and his criteria of continuity and situation, in the interaction 
between the people and their environments, shaped his, and our, understanding of experience. Working with Catarina was an opportunity for experience and shaped how Viviane constructed knowledge for herself about the teaching of and learning process for youth, specifically Catarina, who was composing a life with low vision. Viviane began to narratively understand her personal practical knowledge in relation with Catarina and worked collaboratively with her. For Catarina, feeling part of this research had a personal significance, as she was not treated like somebody outside the landscape, but part of it.

Catarina's morning ${ }^{\text {viii }}$

Seven in the morning.

We are on Summer time, so set the clock one hour later.

It's a sunny day in Brazil.

It's too hot at Escola Aquarela.

I've fallen down in the hall

and some boys have helped me to get up.

I thought nobody would care and help me,

but they did.

I'm trying to listen to the Portuguese Language teacher,

while she explains some grammar rules.

My classmates are funny and talk too much.

The fan is noisy.

I sleep.

(V. Bengezen, based on field note, October 28, 2013).

This word image tells us about Catarina, how she wanted the attention of the boys, how she felt in relation to her classmates, how the environment of her classroom disturbed her, and how she could not pay attention to grammar rules, since the teacher was writing on the board, which she could not see, and she could not hear her teacher. It shows her growing comfort with Viviane as they composed this word image together and as they composed curriculum together. It made Viviane realize Catarina was shaping her own personal practical knowledge just as she was influencing Viviane's.

Reading the above word image about Viviane's work with Catarina, Shaun and Viviane wondered about the position Viviane took up on the knowledge landscape. She began to see how her personal practical knowledge was interwoven with curriculum making (Connelly \& Clandinin, 1988) alongside Catarina as she and Shaun inquired into Viviane's experience with Catarina. Viviane positioned Catarina as a knower, paying attention to what she needed to learn, creating opportunities for Catarina to construct knowledge based on her experience, in order that their time together be educative. In conversation with Shaun, Viviane drew upon Dewey (1938), who writes, "the principle of continuity in its educational application means, nevertheless, that the future has to be taken into account at every stage of the educational process" (p. 47).

The content of Catarina's classes did not have relevance for her because she did not have to respond to anything. Dewey (1902/2008) says that "action is response; it is adaptation, adjustment" (p. 30). Schooling has to make sense for the youth. It is our responsibility as educators to do as Dewey (1902/2008) suggests, "Let the child's nature fulfill its own destiny, revealed to you in whatever of science and art and industry the world now holds as its own" (p. 31). Catarina was active and learned when she was challenged by situations that arose and ones in which she engaged in a reciprocal process. 
The experience of Catarina with her family and friends made sense for Catarina, but when she came to school the world was divided into subjects without connection to her life away from school, reminiscent of Viviane's wonders on the subway at the beginning of this paper. We can discriminate between those experiences that are educative or mis-educative. School for the most part had been a mis-educative experience for Catarina.

Regarding interaction, Dewey (1938) writes, "the principle of interaction makes it clear that failure of adaptation of material to needs and capacities of individuals may cause an experience to be non-educative quite as much as failure of an individual to adapt himself to the material" (p. 46). Catarina's interaction with materials provided by the school also shaped miseducative experiences. She often did not have adapted materials to support her learning, nor was she able to adapt to the materials of school, given the constraints of her low vision. Viviane saw her work, in part, as adapting material to meet Catarina's needs. This was not without tension for Viviane.

When Viviane showed an idea to the other teachers or supervisors about how to work on a topic with Catarina, she felt uncomfortable because she could not express or show what the importance might be for the concept in Catarina's life. One of the most important aspects of their work together was to create opportunities for Catarina to be interested in knowing.

When I develop a different activity with her, for example, when she recorded her voice in English as she talked about her life and described pictures she had taken, or when she read a vocational test and we talked about possible jobs, I saw her interest. (journal entry, November, 2013)

Inquiring into the stories of experiences Viviane lived alongside Catarina on the professional knowledge landscape was an opportunity to study the intersection of their stories to live by, personal practical knowledge, curriculum making, and the tensions they lived in regards to the mandated curriculum designed for all children and applied to Catarina on the Brazilian school landscape. Catarina's personal knowledge landscape and her personal practical knowledge, the dominant stories of school on the professional knowledge landscape, and her familial curriculum making were all interacting and shaping her stories to live by. We need to always stay attentive to ways in which these interactions are shaping youth's stories to live by and wonder if these interactions are shaping educative stories to live by.

\section{Co-composing Curriculum on Diverse Landscapes: The Experience in the Experience}

Inquiring into Viviane's and Catarina's storied experiences, we realized that Viviane was learning to be a different kind of teacher because she had the opportunity to work with Catarina. Conversely, we can posit that Catarina may have been learning to be a different kind of learner alongside Viviane. Catarina and Viviane were involved in identity making. Specifically, Viviane was shifting her personal practical knowledge and her stories to live by as a teacher, in relation with Catarina.

During this inquiry, while working as Catarina's support teacher, Viviane wondered, if she had been Catarina's English teacher in a regular classroom, how might Viviane's understanding of Catarina's curricular needs have evolved. In this moment Viviane wondered if 
she would have given Catarina the standard sheets of paper with exercises to learn the structure of English language, with blanks to be filled with the correct form of the verb. Would Viviane have asked Catarina to copy texts? Might she have asked Catarina to translate English phrases from English to Portuguese?

These wonders made us think about other youth. Inquiring into Viviane and Catarina's experiences together, with Catarina's obvious specific needs, made us consider other youths' needs that might not be so obvious. By developing a curriculum with Catarina, attentive to Catarina's experiences, Viviane began to consider the educative experiences and the miseducative experiences she may have created for other youth in the last five years at the public school where she works.

\section{Curriculum-making with Catarina: Shaping Life-writing Experiences}

The conceptualization of curriculum as a course of life was foundational to our inquiry in this paper. The work of Mello (2003) regarding curriculum also helped us to see possibilities of curriculum making with Catarina. Mello explains:

when you start to study the narratives of experiences of students and teachers, it is difficult to see the curriculum as something pre-established and organized. Curriculum then becomes all the experiences, all the meanings that come from these experiences, and also how one experiences these meanings that generate transformations, projecting moments and future placements. $(\text { p. 25) })^{i x}$

The stories of Catarina and Viviane, their familial stories, and their stories of Escola Aquarela shaped our work.

A vision of curriculum as a course of life, shaped by stories to live by, and teacher's and youth's personal practical knowledge, helped Viviane understand how she and Catarina were shaping a course of life together. We are mindful of the words of Clandinin et al. (2006):

we are drawing attention to the importance of staying wakeful to the experiences children and families are living both in-and out-of-schools, to the dreams children hold for their lives, to the dreams families hold for their children's lives, to the gaps, silences, and exclusions shaped in the bumping places children and families experience in schools. ( $p$. 173)

Inquiring into Viviane's practice with Catarina illustrates the unfolding acts of curriculum making that shaped their experiences. While this paper is about Viviane and Catarina, it is also about curriculum making with all children and youth. It is by staying attentive to curriculum making, understood as a course of life making, that we see significant possibilities for growing, and sustaining, family, school, and community partnerships.

This paper is also about how a teacher educator, Shaun, came alongside a teacher, Viviane, to help her understand who she is, and is becoming, as a teacher. It is a story of teacher education and the importance of teachers and teacher educators learning to think about and understand curriculum making. 


\section{References}

Clandinin, D. J., \& Connelly, F. M. (1992). Teacher as curriculum maker. In P. W. Jackson (Ed.), Handbook of research on curriculum (pp. 363-401). New York, NY: Macmillan.

Clandinin, D. J., \& Connelly, F. M. (1994). Personal Experience Methods. In N. K. Denzin \& Y. S. Lincoln (Eds.), Handbook of Qualitative Research (pp. 413-427). Thousand Oaks, CA: Sage Publications.

Clandinin, D. J., \& Connelly, F. M. (1995). Teachers' professional knowledge landscapes. New York: Teachers College Press.

Clandinin, D. J., \& Connelly, F. M. (2000). Narrative Inquiry: Experience and story in qualitative research. San Francisco: Jossey Bass.

Clandinin, D. J., Huber, J., Huber, M., Murphy, M. S., Pearce, M., Murray-Orr, A., \& Steeves, P. (2006). Composing diverse identities: Narrative inquiries into the interwoven lives of children and teachers. London, UK: Routledge.

Clandinin, D.J. \& Rosiek, J. (2007) Mapping a landscape of narrative inquiry: Borderland spaces and tensions. In D.J. Clandinin (Ed.), Handbook of narrative inquiry: Mapping methodology (pp. 35- 75). Thousand Oaks, CA: Sage Publications.

Clandinin, D. J., \& Murphy, M. S. (2009). Comments on Coulter and Smith: Relational ontological commitments in narrative research. Educational Researcher, 38(8), 598-602.

Clandinin, D. J., Schaefer, L., \& Downey, C. A. (2014) Narrative conceptions of knowledge: Toward understanding teacher attrition. Bingley, UK: Emerald Group Publishing Limited.

Clandinin, D. J., Huber, J., \& Murphy, M. S. (2011). Familial curriculum making: Re-shaping the curriculum making of teacher education. International Journal of Early Childhood Education, 17(1), 9-31.

Connelly, F. M., \& Clandinin, D. J. (1988). Teachers as curriculum planners: narratives of experience. New York, NY: Teachers College Press.

Connelly, F. M., \& Clandinin, D. J. (1999). Shaping a professional identity: Stories of educational practice. New York, NY: Teachers College Press.

Connelly, F. M., \& Clandinin, D. J. (2006). Narrative inquiry. In J. Green, G. Camilli, \& P. Elmore (Eds.), Handbook of complementary methods in education research, (pp. 477487). Mahwah, NJ: Lawrence Erlbaum.

Dewey, J. (1938). Experience and education. New York, NY: Macmillan. 
Dewey, J. (2008). The child and the curriculum including, The school and society. New York, NY: Cosimo Classics.

Huber, J., \& Clandinin, D. J. (2005). Living in tension: Negotiating a curriculum of lives on the professional knowledge landscape. Advances in research on teaching, 11, 313-336. Doi: 10.1016/S1479-3687(05)11011-6

Huber, J., Murphy, M. S., \& Clandinin, D. J. (2003) Creating communities of cultural imagination: Negotiating a curriculum of diversity. Curriculum Inquiry, 33(4), 343-362.

Huber, J., Murphy, M. S., \& Clandinin, D. J. (2011). Places of curriculum making: Narrative inquiries into children's lives in motion. Bingley, UK: Emerald Group Publishing Ltd.

Mello, D. M. (2003). Histórias de subversão do currículo, conflitos e resistências: buscando espaço para a formação do professor na aula de língua inglesa do curso de Letras. 2004. 225 f. Tese (Doutorado em Linguística)-LAEL, Pontifícia Universidade Católica de São Paulo, São Paulo.

Murphy, M. S. (2004). Understanding children's knowledge: a narrative inquiry into school experiences. (Unpublished doctoral dissertation).University of Alberta, Edmonton, AB.

Murphy, M. S. (2009). Stories in relationship: Experience, identity, and curriculum making in an elementary classroom. LEARNing Landscapes, 2(2), 109-121.

Murphy, M. S. (2011). Poetry from report cards: Children's understanding of themselves in relationship to their teachers. In C. Craig \& L. Deretchin (Eds.), Cultivating curious and creative minds (pp. 245-261). Lanham, MD: Rowman \& Littlefield Education.

Murphy, M. S., Huber, J., \& Clandinin, D. J. (2012). Narrative inquiry into two worlds of curriculum making. LEARNing Landscapes, 5(2), 219-236.

Sarbin, T. R. (2004). The role of imagination in narrative construction. In C. Daiute \& C. Lightfoot (Eds.), Narrative analysis: Studying the development of individuals in society, (pp. 5-20). Thousand Oaks, CA: Sage Publications.

Schwab, J. J., Westbury, I., \& Wilkof, N. J. (1978). The Practical: Translation into Curriculum. In Anonymous (Ed.), Science, curriculum, and liberal education: Selected essays (pp. 365-383). Chicago, IL: University of Chicago Press.

\section{Notes}

${ }^{\text {i }}$ The Specialized Educational Service is responsible for those students who have any kind of disability at municipal schools in the city where the inquiry was situated.

${ }^{\text {ii }}$ CEMEPE is a Municipal Center of Studies and Projects of the city in the inquiry.

iii Virtual Vision is a software which can help visually impaired people to use Windows, Office, Internet Explorer and other applications, through reading the menus and screens of these programs by a voice synthesizer.

${ }^{\text {iv }}$ Catarina is a pseudonym. All names of participants and places are pseudonyms in this work to protect the anonymity of the participants. 
${ }^{v}$ Clandinin, Schaefer, and Downey (2014) explain the personal knowledge landscape as, "the knowledge landscape we come to know first. It is within personal knowledge landscapes shaped by social, cultural, linguistic, familial, and institutional narratives that our first stories to live by come into being. It is within those early personal knowledge landscapes that we begin to live out our stories to live by and, in living out those stories to live by, our identities are continuously in the making. (p. 185)

${ }^{\text {vi }}$ Clandinin and Connelly (1995) describe of the professional knowledge landscape: The landscape metaphor is particularly well suited to our purpose. It allows us to talk about space, place, and time. Furthermore, it has a sense of expansiveness and the possibility of being filled with diverse people, things, and events in different relationships. Understanding professional knowledge as comprising a landscape calls for a notion of professional knowledge composed of a wide variety of components and influenced by a wide variety of people, places, and things. Because we see the professional knowledge landscape as composed of relationships among people, places, and things, we see it as both an intellectual and moral landscape. (p. 5)

${ }^{\text {vii }}$ School caused an interruption in her continuity of experience, leading to what Dewey (1938) termed as miseducative experiences. Dewey explained, "there is some kind of continuity in any case since every experience affects for better or worse the attitudes which help decide the quality of further experiences" (p. 37).

viii Viviane composed this word image from a field note she had made regarding a conversation she had with Catarina. In it Viviane is attentive to Catarina, and as Viviane and Shaun read it they noted the significance of Viviane paying attention to Catarina's life in school.

${ }^{\mathrm{ix}}$ In the original Portuguese: quando se começa a estudar as narrativas de experiências de alunos e professores, torna-se difícil ver o currículo como algo pré-estabelecido e organizado. Currículo passa a ser então todas as experiências vividas, todos os significados que se obtêm dessas experiências, e também a forma como se vivencia esses significados que geram transformações, projetando momentos e posicionamentos futuros.

M. Shaun Murphy is an Associate Professor in the Department of Educational Foundations at the University of Saskatchewan. His research interests are based in relational narrative inquiry and focus on familial and school curriculum making; the interwoven lives of children, families, and teachers; and teacher education.

Email: shaun.murphy@usask.ca

Viviane C. Bengezen is an English Teacher at Escola Municipal Professor Otávio Batista Coelho Filho, in Uberlândia, Brasil. She is a narrative inquirer, with interests in authorship, voice, and signature of teachers and students at public schools.

Email: vbengezen@gmail.com 